Meta

Journal des traducteurs

Translators' Journal

\title{
Teaching Translation in Israel High Schools
}

\section{Ely Kozminsky, Elda Weizman et Hannah Horowitz}

Volume 43, numéro 1, mars 1998

La traduction et l'interprétation en Israël

Translation and Interpreting in Israel

URI : https://id.erudit.org/iderudit/003349ar

DOI : https://doi.org/10.7202/003349ar

Aller au sommaire du numéro

Éditeur(s)

Les Presses de l'Université de Montréal

ISSN

0026-0452 (imprimé)

1492-1421 (numérique)

Découvrir la revue

Citer cet article

Kozminsky, E., Weizman, E. \& Horowitz, H. (1998). Teaching Translation in Israel High Schools. Meta, 43(1), 119-129. https://doi.org/10.7202/003349ar

\section{Résumé de l'article}

Cet article décrit le programme d'études de traduction anglais-hébreu, dans les écoles secondaires en Israël. Il analyse les résultats d'une étude empirique destinée à évaluer les effets de ce programme sur le niveau des élèves. Le programme consiste en un cours hebdomadaire de deux heures offert aux élèves des deux dernières années du lycée. Ceux-ci tradui- sent de l'anglais vers l'hébreu et pratiquent l'analyse textuelle des problèmes de traduction en vue de développer leur conscience méta-linguistique tout en améliorant leurs connaissances linguistiques dans les deux langues. 


\title{
TEACHING TRANSLATION IN ISRAELI HIGH SCHOOLS
}

\author{
ELY KOZMINSKY \\ Ben-Gurion University, Israel \\ ELDA WEIZMAN \\ Bar-Ilan University, Israel \\ HANNAH HOROWITZ \\ Ben-Gurion University, Israel
}

\begin{abstract}
Résumé
Cet article décrit le programme d'études de traduction anglais-hébreu, dans les écoles secondaires en Israël. Il analyse les résultats d'une étude empirique destinée à évaluer les effets de ce programme sur le niveau des élèves. Le programme consiste en un cours hebdomadaire de deux heures offert aux élèves des deux dernières années du lycée. Ceux-ci traduisent de l'anglais vers l'hébreu et pratiquent l'analyse textuelle des problèmes de traduction en vue de développer leur conscience méta-linguistique tout en améliorant leurs connaissances linguistiques dans les deux langues.
\end{abstract}

\begin{abstract}
The paper describes the English Language Translation Program (LTP), as it is implemented in Israeli high schools. It further discusses the results of an empirical study designed to evaluate the students' achievements following the program. The LTP is a two-year option for the 11th and 12th grades. In a two-hour weekly course they practice written translation from English (L2) into Hebrew (L1), and discuss textually relevant translation problems with the aim of increasing language awareness and developing language competence. Evaluation of the program at the end of 1994 indicated that the LTP students improved the metalanguage skills related to translation, and also gained 5 extra percentage points in the regular English matriculation exams at the end of grade 12, compared to the non-LTP controls. Administrative, pedagogical, and conceptual problems in implementing the program are discussed.
\end{abstract}

In the last decade, certain aspects of translation have been introduced into the Israeli high school curriculum, first as an experimental program (1985-1989), and then as an optional subject for the upper division (as from 1989). The introduction of translation as an independent subject into the English Language Teaching (ELT) in Israeli high schools represents a spiral closure of language teaching approaches. In this paper we would like to present the English Language Translation Program (LTP), as it is implemented in the high school system, and evaluate its achievements. After briefly delineating the historical development of Foreign Language Teaching (FLT) approaches, we will describe the translation program. Then we will present results of an empirical study designed to evaluate the LTP in promoting insight into native (first language - L1) and foreign (second language L2) languages and improving English language skills ${ }^{1}$.

Meta, XLIII, 1, 1998 


\section{LANGUAGE TEACHING AND TRANSLATION}

The use of translation as an inherent part of FLT was prevalent until early in the present century. The Grammar-Translation method, dominant during the first half of the century, stressed translation and grammatical analysis, and put greater emphasis on accuracy than on fluency, preferring academic erudition to communicative competence (Titone $\&$ Danesi 1985). At the turn of the century, the Grammar-Translation method gradually gave way to the Direct Method (more characteristic of ELT in Europe than in America (Rivers 1991)), which advocated maximum exposure to the target language, with no recourse either to L1 or to translation. During this period, "Translation used to be regarded as a necessary evil" (Levenston 1985a). The Direct Method made its way very prominently into the field of ELT in Israel during the British Mandate (Bamberger 1958).

The American behaviorist school (Skinner 1938; Watson 1913) of language teaching ushered in the Audio-lingual Method, which concentrated on patterns and structure with an emphasis on drill and technique. The product, not the process, was important; there was to be minimal explanation of rules and no recourse to translation (Larsen-Freeman 1962). The reaction to the audio-lingual method, grounded in the Chomskian Revolution, was the Communicative Approach (Ministry of Education 1988; Savignon 1987). Communicative competence "has come to be used in language teaching contexts to refer to the ability to negotiate meaning, to successfully combine a knowledge of linguistic and sociolinguistic rules in communicative interactions"(Savignon 1987: 16). At the same time, the advance of cognitive psychology, which was also influenced by the Chomskian revolution, made an impact on ELT (Titone \& Danesi 1985). The findings of cognitive psychology indicated that "deductive, or rule-based, strategies play a prominent role in language learning. Deductive teaching methods are therefore based on the learning principles of cognitive psychology and its linguistic counterpart, transformationalism, and are generally known as cognitive-code procedures" (Titone \& Danesi 1985: 110). "The role of the teacher is to recognize the importance of mental activity in learning" (Chastain 1971: 92).

Teachers of FLT were now called upon to address the problems of consciousnessraising. (Bialystok 1986, 1988; Carrel 1989; Castillo 1991; Cohen 1986; Gerloff 1986; Hosenfeld 1978; Kern 1989; Rivers 1991; Rubin 1975; Templeton 1989; Thomas 1988; Vieira 1991; Wenden \& Rubin 1987). It came to be realized that the study of translation skills might have value as a means of raising the learner's linguistic awareness with regard to his or her native as well as to the foreign language (Boersch 1986; Carton 1966, cited by Rubin 1986; Faerch \& Kasper 1986; Hosenfeld 1978; Lehmann 1986; Levenston 1985b; Loerscher 1986; Ministry of Education 1990; Naiman 1978, quoted by Levenston 1985a; Rosenblith, stated in Ackerman 1992; Sharwood Smith 1981; Titford 1983). The contrastive analysis of the two languages, L1 and L2, which accompanies the translation process, is presumed to heighten the learner's metalinguistic awareness of both languages and to facilitate their perception as abstract language systems. This is the raison d'être of the program which is described below.

\section{THE ISRAEL ENGLISH LANGUAGE TRANSLATION PROGRAM}

English is taught as a second language in Israeli schools from grade four (age ten), starting with a frequency of two weekly lessons and increasing to five in the upper division (grades 10-12) of high school. It is a mandatory subject for the matriculation exams at the end of high school ${ }^{2}$. Based on past achievements and students' choice, the upper division academic trend students study English at varying levels of intensity: a school leaving exam $^{3}$ only, a three-point, four-point, or five-point matriculation exam ${ }^{4}$. While at the 
school leaving exam, students are expected to understand "the overall message [...] of genres such as [...] instructions, or a short narrative" (Steiner 1995: 20), five-point matriculation candidates are expected "to follow the development of an argument" and "to recognize the attitudes of writers implicit in authentic passages" which include "genres such as [...] newspaper articles or expository texts" (Steiner 1995: 21). Translation studies are not part of these requirements 5 .

In 1983, Raphael Gefen, at the time Chief Inspector for English, published a paper advocating the introduction of translation skills into the secondary school English curriculum (Gefen 1982). From 1985 to 1991 translation was taught in the 11th and 12th grades as an experimental program "as a distinct skill, additional to the four basic language skills [...] Reading [...] Listening Comprehension, Oral and Written Expression" (Gefen 1985: $3)$.

The 1988-89 school year saw the introduction of Translation Skills (HebrewEnglish, English-Hebrew) as an "optional subject for the Upper Division in the State and State-Religious schools". While before 1988-89 translation was an experimental program, from 1988-89 it was taught in the 11th and 12th grades as an independent course for two matriculation points. The LTP syllabus was prepared by a committee appointed by the Curriculum Centre of the Ministry of Education, and it was "designed to enable pupils to acquire an understanding of the skills of translation and an adequate proficiency in translating written materials of different kinds" (Ministry of Education 1990: 3). More specifically, the aims of the program are:

"- to develop the learner's insight into the nature and significance of language as such, as a result of the confrontation between the mother tongue and the foreign language while searching for equivalence in meaning.

- to stimulate in the learner an intellectual and linguistic challenge.

- to broaden the learner's competence in the mother tongue and the foreign language.

- to show the learner how to balance the competing claims of accuracy and fidelity to the source on the one hand, and appropriacy and idiomacity in the target language on the other." (Ministry of Education 1990: 3)

Given the above mentioned aims, it is clear that translation is not conceived of as an end in itself, but rather as a means of increasing language awareness and developing language competence.

The LTP is an option for Upper Division High schools. To take the program, students must have reached a high level of proficiency (at least 85/100) both in Hebrew and in English by the end of the 10th grade. Students study in the program in the 11th and 12th grades. They are taught two hours weekly, and take the final matriculation exam at the end of grade 12. In 1991 a total of 54 students throughout the country sat for this examination. In 1992, 1993, 1994 and 1995, the examination was taken by 149, 270, 335, and 288 students respectively, and, as from 1992 it was marked externally, i.e. not by the teachers of the schools. All the students that entered the program also took the regular five-point English matriculation program.

Since the program focuses on English-Hebrew translation, teachers should have mother-tongue mastery in Hebrew, and an excellent command of English. In addition, they are required to undergo an appropriate course of training. Indeed, in the period in question most of the teachers fulfilled both requirements. While we have not conducted a systematic study of the classroom environment, personal observations have revealed certain teaching characteristics: compared with regular FL teaching, the translation lesson is usually conducted in an informal setting, reflecting a more egalitarian teacher-student rela- 
tionship. Frequent teacher-student and peer collaboration seems to be related to the nature of translation as a problem-solving activity, as well as to the fact that translation students are high achievers in both English and Hebrew in their schools. At the period of study, classroom discourse was probably affected also by the absence of textbooks - although guidelines and practice text examples were available (Levenston 1985b). A course textbook is currently being written (Rosenblüth and Ballas in preparation).

As we have mentioned, the program does not set out to train translators. However, the major part $(70 \%)$ of the grade for the matriculation examination is allotted to the translation of a text from L2 (mostly English) to L1 (mostly Hebrew) ${ }^{6}$, while only $30 \%$ is allocated to the explanation of problems or difficulties encountered in the translation of certain words or expressions. Most of the texts in the examinations are newspaper articles or essay type passages, although, during instruction, the teachers and students are free to select texts of their own choosing. In the examinations, students are guided in their explanation of difficulties or problems in translation: "What were the difficulties [...] you faced in choosing your [...] translation (idioms, grammatical structures, ambiguities, fidelity to the source language and the specific style of the passage, etc.)?" The students are given two hours in which to translate a passage of about 350-400 words (200-250 words from 1994) and discuss the translation of 10 items specified in the text ${ }^{7}$.

\section{PROGRAM EVALUATION}

In order to evaluate the LTP, we assumed that studying for the translation program heightens students' metalinguistic awareness as evinced in their competence in L1 and L2 (Ministry of Education 1990). We also assumed that this change in metalinguistic awareness affected the students' general English language achievements. In order to test these assumptions, we investigated (a) the differences in linguistic insights of L1 and L2, between students who have studied translation and comparable students who have not done so; and (b) the differences in the standard achievements in English (matriculation exams) at the end of high school between those groups of students.

\section{Selection of Schools}

In selecting the schools for the present study, the main consideration was the anticipated number of students who would eventually take the LTP. At the beginning of the 1991-92 school year, 38 schools were listed as prospective candidates for the program. Of these, only eight proved to be eligible by virtue of having a sufficient number of students who were expected to take the LTP. Of these eight schools, two were selected for a pilot study that was designed to develop the evaluation tasks and could therefore not be included in the main study. Another school was struck off the list because its students had already embarked on the translation program in grade 10, and the pre-test (to be administered to students who have not been exposed to the translation program) would therefore have had no validity. This left five schools. In these schools we selected, in the spring of 1992, 234 10th-grade students. These were of good standing, and were estimated by their teachers as potential candidates for the 4- or 5-point matriculation examinations in 1994.

\section{Evaluation Procedure}

Based on the pilot study, we designed assignments that were similar in their structure to the explanation component of the translation matriculation test ${ }^{8}$. The assignments were administered in April-May 1992, before the students entered the LTP in the 10th grade (pre-test), and in December-January 1993-94, in the 12th grade, towards the end of the program, before the matriculation examinations (post-test). On each occasion, the stu- 
dents received two passages, one in English (pre-test: 264 words; post-test: 286 words) and one in Hebrew (pre-test: 320 words; post-test: 323 words). The passages were unadapted, non-academic newspaper articles and comparable in terms of potential translation problems, e.g. grammatical and conceptual voids, modals, verbal phrases, collocations and metaphors (cf. Weizman \& Kozminsky, in preparation).

In each passage, the students were instructed to select five words or phrases that they considered difficult or problematic for translation. For each selection, the students were asked to provide in Hebrew an explanation of the translation problem or difficulty. No access to dictionaries or thesaurus was allowed, and no external "cooperation" was provided in completing the assignment.

In addition to the explanation assignment, we collected from students' files information about their school performance, starting from 10th-grade English marks to the matriculation examination marks. The students also provided information about their out-ofschool language environment, e.g., language(s) spoken at home, time spent abroad, etc.

By the time of the post-test, it transpired that three of the five schools who had taken the pre-test had abandoned the translation program altogether, leaving only two schools (School R and School G), with a total of 56 students who had taken the pre-test and the post-test, 16 of whom were translation students, who also took the 5-point English matriculation exam, and 40 non-translation (regular) students. Of the 40 non-translation students, 24 students actually took the 5-point English matriculation exam. The remaining students took the 4-point matriculation exam and were excluded from the analysis. There were no gender distribution differences among the students who chose the LTP versus the non-translation students $(\mathrm{c} 2(1)=.07, \mathrm{P}=.79)$. Of the 16 translation students, 10 were males and 6 were females, while of the 24 non-translation students 16 were males and 8 were females.

The average duration of the explanation assignments was well within the maximum time limit allotted for each passage. The pre-test maximum time limit was 45 minutes per passage; actual average duration was 13.7 minutes for the English and 11.2 minutes for the Hebrew text. Based on the pre-test, the maximum time limit for the post-test was 25 minutes per passage; actual average durations were 11 minutes for the English and 7.8 minutes for the Hebrew text.

The explanation assignments were analyzed on three levels or categories. The categories were defined as follows: did the explanation contain: (a) terminology; (b) a comparison between languages (the interlingual level); or (c) a reference to the occurrence of a problem or a suggested solution (the contextual level).

The coding scheme devised for the last two categories was as follows:

\section{The Interlingual Level}

"-" missing explanation, a stereotyped cliché, or failure to relate on that level;

"0" an erroneous definition;

"1" reference to one of the languages, implying a comparison with the other;

"2" an explicit or implicit comparison between the two languages;

"3" an exceptionally comprehensive definition.

\section{The Contextual Level}

"-" missing explanation, a stereotyped cliché, or failure to relate on that level;

"0" an erroneous definition;

"1" an implicit or explicit explanation of the occurrence or a suggested solution;

"2" an implicit or explicit explanation of the occurrence and a suggested solution;

"3" an exceptionally insightful definition. 
$10 \%$ of the explanation assignments were coded independently and then discussed by the last two authors of this paper. Then a second batch of $10 \%$ of the assignments was independently coded by both researchers, and a consensus of more than $80 \%$ was reached.

For the purpose of a quantitative analysis, as presented below, the interlingual and contextual levels were combined as follows:

1) The first two categories on each level were considered as " 0 ".

2) The numbers "0"-"3" were assumed to represent an increasing quality on an interval scale.

3) An average score was computed for the students' scores on both levels.

A summary of the English and the Hebrew assignments is presented in Table 1. As can be seen, the LTP students' explanations, in both the English and the Hebrew translation assignments, improved significantly from a level of almost no explanation or incorrect ones to a level of medium-quality explanations, while the level of explanation of the regular students remained at its low level (Analysis of Variance, English: $F(1,36)=32.00$, Hebrew: $\mathrm{F}(1,36)=23.45, \mathrm{p}<.05)$.

\begin{tabular}{|c|c|c|c|}
\hline \multicolumn{4}{|l|}{ (a) English } \\
\hline Students & $\mathbf{N}$ & Pre-test & Post-test \\
\hline Translation & 16 & $\begin{array}{c}0.31 \\
(0.36)\end{array}$ & $\begin{array}{c}1.04 \\
(0.61)\end{array}$ \\
\hline Regular & 24 & $\begin{array}{c}0.17 \\
(0.27)\end{array}$ & $\begin{array}{c}0.11 \\
(0.23)\end{array}$ \\
\hline \multicolumn{4}{|l|}{ (b) Hebrew } \\
\hline Students & $\mathbf{N}$ & Pre-test & Post-test \\
\hline Translation & 16 & $\begin{array}{c}0.22 \\
(0.32)\end{array}$ & $\begin{array}{c}0.91 \\
(0.69)\end{array}$ \\
\hline Regular & 24 & $\begin{array}{c}0.23 \\
(0.27)\end{array}$ & $\begin{array}{c}0.19 \\
(0.25)\end{array}$ \\
\hline
\end{tabular}

Table 1

Pre- and post-test translation assignment mean scores (Max. $=3$ ) and standard deviations (in parentheses) for translation and regular (non-translation) students.

(a) English (into Hebrew) translation; (b) Hebrew (into English) translation.

These results provide an answer to the first evaluation question: are there differences in the quality of L1 and L2 translation explanations between students who have studied translation in comparison to students who have not done so? The LTP did in fact improve students' ability to explain translation difficulties, both from Hebrew into English and from English into Hebrew. This is due, we conjecture, to heightened metalinguistic awareness. This was corroborated by a more intensive qualitative analysis which provided detailed understanding of the students' development, as a result of the LTP. This analysis will be described elsewhere (Weizman \& Kozminsky, in preparation). 
In order to answer the second question, namely, did the LTP effect a change in the English achievement standard (matriculation exam) at the end of high school among the LTP students, as compared with regular students, we had first to examine their achievements at the 10th grade. It was to be expected that the teachers' recommendation to the students and the students' own decision to enter the LTP were influenced by their achievements, as well as by a host of other considerations. The English school marks at the end of grade 10 are displayed in Table 2. Since school grading policy and/or students' ability might have been different, the results are presented according to schools. Indeed, there was a 7 point difference (Analysis of Variance: $\mathrm{F}(1,36)=6.22$, $\mathrm{p}=.02$ ), which represents a 0.75 standard deviation difference between the schools: School $G$ had weaker students, or a more stringent grading policy than School R. The difference between the students who entered the LTP and the regular students was 10.6 marks (Analysis of Variance: $\mathrm{F}(1,36)=15.30, \mathrm{p}=.0004)$, or a 1.09 standard deviation difference. We can, therefore, conclude that it was the better students who entered the LTP.

\begin{tabular}{|l|c|c|c|}
\hline \multicolumn{1}{|c|}{ Program School } & Translation & Regular & Total \\
\hline School R & & & 87.7 \\
Mean & 93.1 & 83.3 & 9.1 \\
SD & 5.1 & 9.4 & 20 \\
N & 9 & 11 & \\
\hline School G & & & 80.4 \\
Mean & 86.9 & 76.9 & 9.0 \\
SD & 9.7 & 6.7 & 20 \\
N & 7 & 13 & 84.0 \\
\hline Total & 90.4 & & 9.7 \\
Mean & 7.9 & 79.8 & 40 \\
SD & 16 & 8.5 & 24 \\
N & & & \\
\hline
\end{tabular}

Table 2

English school marks (means, standard deviations, and number of students) at the end of 10th grade.

At the end of the grade 12 we examined the English matriculation grades (average of the matriculation external exam marks and the school internal exam marks). These grades are displayed in Table 3. The relative difference between schools $\mathrm{R}$ and $\mathrm{G}$ (11.3 marks) was maintained or even increased, which meant that School G had weaker students than School R rather than a stringent grading policy. Also, the difference between the LTP and the regular students (12.5 marks) was maintained. However, we had to examine these differences after controlling for the differences in students' English achievements in grade 10. That is, we adjusted within each school for the better English grades that LTP students had in grade 10, so that the adjusted English matriculation grades are considered as though the LTP and regular students had the same average grades in grade 10. The adjusted 
English matriculation grades are presented in Figure 1. Of course, the average difference between school R (89.2) and school G (78.9) remained the same (Analysis of Covariance: $\mathrm{F}(1,35)=84.22, \mathrm{p}=.0000)$. The average adjusted matriculation grade was 86.7 for the LTP students and 81.5 for the regular students. This represents a net advantage of 5.2 matriculation marks of the LTP over the regular students (Analysis of Covariance: $F(1,35$ ) $=14.93, \mathrm{p}=.0005)$. Another interesting pattern of results in Figure 1 is the relatively steeper improvement (7.9 marks) of the LTP students (82.9) versus the regular students (75.0) of School G, as compared with the improvement (2.3 marks) of the LTP students (90.4) versus the regular students $(88.1)$ of School $R$ (Analysis of Covariance: $F(1,35)=$ $6.42, \mathrm{p}=.02$ ). That is, after factoring out the relative entrance advantage of the LTP students, the weaker students (School G) benefited more from the translation program than the stronger ones (School R).

\begin{tabular}{|l|l|l|l|}
\hline Program School & Translation & Regular & Total \\
\hline School R & & & \\
Mean & 93.9 & 85.2 & 89.1 \\
SD & 3.6 & 7.7 & 7.5 \\
N & 9 & 11 & 20 \\
\hline School G & & & \\
Mean & 87.1 & 72.7 & 77.8 \\
SD & 7.4 & 5.2 & 9.2 \\
N & 7 & 13 & 20 \\
\hline Total & & & \\
Mean & 90.9 & 78.4 & 83.4 \\
SD & 6.4 & 8.9 & 10.1 \\
N & 16 & 24 & 40 \\
\hline
\end{tabular}

Table 3

English matriculation marks (means, standard deviations, and number of students)

\section{SUMMARY AND DISCUSSION}

\section{English Proficiency}

The results indicate that after controlling for the selection of students to the LTP, i.e., the students who entered the program had higher English achievements in the 10th grade compared with regular students, the net effect of LTP was 5 marks in the English matriculation examination. Moreover, students with a lower 10th grade English achievement (School G) benefited more from LTP than their high achieving counterparts (School R).

This success should lead many more students to choose the program. But in practice the program remains limited in scope. First, the students and even their teachers are not aware of this extra benefit to their English, and perhaps general, language ability.

More importantly, the two matriculation points of the LTP are not perceived by the students as "beneficial" in terms of the entry requirements at university level, because they 
do not provide a significant extra bonus. The Ministry of Education determined that the LTP would receive only a regular weight in the general matriculation point average, compared with extra weight given to other five-point or more programs. This is an organizational problem that could be solved by developing a seven-unit English curriculum, or by incorporating the LTP into the regular English program.

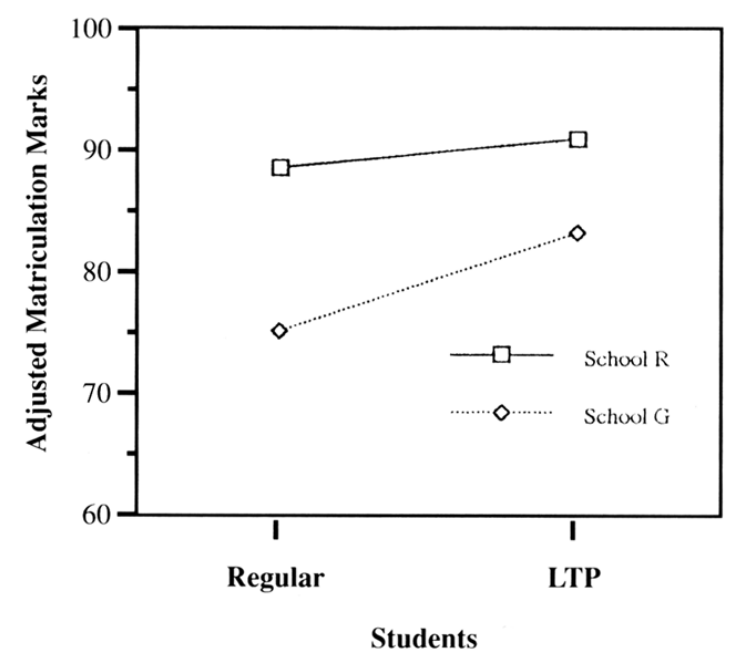

Figure 1

LTP and regular students English matriculation marks adjusted for grade 10 English marks, for schools R and G.

Third, the fact that weaker students benefited more (an addition of eight matriculation marks) from LTP than the stronger students (two additional marks) suggests that students with a lower 10th grade English achievement should be accepted for the program, rather than just the highest achievers.

\section{Metalinguistic Awareness}

The results also indicate that compared with regular students, LTP students increased their metalinguistic awareness following participation in the translation program, as was evident from the improvement in the quality of their translation explanations. This improvement was similar for both L2 to L1 and L1 to L2 translation explanation tasks. Did LTP increase metalinguistic awareness in general? Or did it affect specific English language skills? Further analysis of the qualitative data, relying on the coding scheme introduced above, may also provide us with some insights into the nature of metalanguage skills most likely to be developed through translation and through the discussion of problem-solving procedures.

Answers to these questions have implications as to when and how to incorporate the program within the general school curriculum. Should it be a special program or should it be part of the general English curriculum? Or perhaps the program could be part of a general Language Arts curriculum, in which contrastive linguistic elements are taught, both 
within language (L1), and across languages (L1 vs L2), and which focuses on awareness of language processes, rather than on mastery of rules and language structures.

Answers to these pedagogical and theoretical questions are beyond the scope of the present article. While an in-depth study of the qualitative data is reported in Weizman and Kozminsky (in preparation), we would like to encourage a longitudinal study of the program, which will develop some of the thoughts put forward in this paper.

\section{Notes}

1. The study reported here is part of an M.A. thesis (Horowitz, in preparation).

2. In the Israeli system of matriculation (Bagrut in Hebrew) students are externally examined in several subjects. There are mandatory and elective subjects at various levels of proficiency, measured by number of points, from one to five. The matriculation point system in English and various other subjects is used as a part of entry criteria to university level studies.

3. From 1995, regarded as a one-point matriculation exam.

4. For example, data obtained for 1994 from the Ministry of Education indicates the following distribution of students: $3 \%$ of the students took the school leaving exam, $24 \%$ - the three-point, $36 \%$ - the four-point, and $37 \%$ - the five-point matriculation exam (total number of students was 56,257).

5. For a recent detailed description of the levels of proficiency for the four skills at the different matriculation levels, see Steiner (1995).

6. Given the small number of candidates for the Hebrew-into-English Bagrut Translation examination, a school wishing to enter students for this exam is required, as from the summer of 1996 , to compile its own examination paper and submit it to the English Inspectorate for approval prior to the date of the examination.

7. This concise overview is not intended as a comprehensive account of the development of the program. Among the changes that have been introduced into this general format, one might note, for example, the attempt to reduce the number of discussion items (5 in 1994), and the increase in guidance procedures (in 1997, the number of translation-problems relevant for each marked item was specified).

8. Unlike the matriculation exam, the students were not asked to actually translate their selections.

\section{REFERENCES}

ACKERMAN, S. (1992): "Hebrew-English translation reveals cultural dimensions", Jerusalem Post, April 10.

BAMBERGER, I. D. (1958): Foreword to R. M. Regberg, English as a second language, Tel Aviv, "Otzar Hamoreh", Teachers' Union, pp. 3-7.

BIALYSTOK, E. (1986): "Factors in the growth of linguistic awareness", Child Development, 57, pp. 498-510.

BIALYSTOK, E. (1988): "Levels of bilingualism and levels of linguistic awareness", Developmental Psychology, 24 (4), pp. 560-567.

BOERSCH, S. (1986): "Introspective methods in research on interlingual and intercultural communication", J. House \& S. Blum-Kulka (Eds), Interlingual and Intercultural Communication, Tübingen, Gunter Narr, pp. 195-209.

CARREL, P. (1989): "Metacognitive awareness and second language reading", The Modern Language Journal, 73 (ii), pp. 121-134.

CARTON, A. (1966): The Method of Inference in FL Study, The Research Foundation of the City of New York.

CASTILLO, R. (1991): "Teaching learners to learn", English Teaching Forum, XXIX (3), pp. 28-30.

CHASTAIN, K. (1971): The Development of Modern Language Skills: Theory to Practice, Philadelphia, Center for Curriculum Development.

CHOMSKY, N. (1959): "A Review of 'Verbal behavior' by B. F. Skinner", Language, 35 (1), pp. 26-58.

COHEN, A. (1986): "Studying learner strategies: how we get the information", A. Wenden \& J. Rubin (Eds), Learner Strategies in Language Learning, New Jersey, Prentice-Hall International, pp. 31-40.

FAERCH, C. \& G. KASPER (1986): "One learner - two languages", J. House \& S. Blum-Kulka (Eds), Interlingual and Intercultural Communication, Tübingen, Gunter Narr, pp. 211-228.

GEFEN, R. (1982): "Discussion paper: Introducing the skill of translation as one of the skill taught in secondary schools (Grades 11-12) and tested in the Bagrut examination", English Teachers' Journal (Israel), 27, pp. 11-14.

GEFEN, R. (1985): "Preface" to E. A. Levenston (Ed.), Translation from English to Hebrew: A Course for Schools, Ministry of Education, Israel, pp. 3-4.

GERLOFF, P. (1986): "Second language learners' reports on the interpretive process: Talk-aloud protocols of translation", J. House \& S. Blum-Kulka (Eds), Interlingual and Intercultural Communication, Tübingen, Gunter Narr, pp. 243-262. 
HOROWITZ, H. (in preparation): The Study of Translation Skills as a Means of Broadening the Learner's Competence in the Mother Tongue and in the Foreign Language, M.A. thesis, Ben-Gurion University.

HOSENFELD, C. (1978): "Students' mini-theories of 2nd language learning", Association Bulletin, 29 (1).

KERN, R. G. (1989): "Second language reading strategy instruction: Its effect on comprehension and word inference ability", The Modern Language Journal, 73 (ii), pp. 136-148.

LARSEN-FREEMAN, D. (1962): "Twenty-five years of language learning methodology", English Teaching Forum, XXV (4), pp. 2-10.

LEHMANN, V. (1986): "Understanding in Translation and FLT", J. House \& S. Blum-Kulka (Eds), Interlingual and Intercultural Communication, Tübingen, Gunter Narr, pp. 139-149.

LEVENSTON, E. A. (1976): "Towards a comparative stylistics of English and Hebrew: The insights revealed by translation", English Teachers' Journal, 15, pp. 16-22, reprinted in English Teachers' Journal (Israel), 43, pp. 78-85.

LEVENSTON, E. A. (1985a): "The place of translation in the foreign language classroom", English Teachers' Journal (Israel), 32, pp. 33-43.

LEVENSTON, E. A. (1985b): Translation from English to Hebrew: A Course for Schools, Ministry of Education, Israel.

LOERSCHER, W. (1986): "Linguistic aspects of translation processes", J. House \& S. Blum-Kulka (Eds), Interlingual and Intercultural Communication, Tübingen, Gunter Narr, pp. 227-292.

Ministry of Education (1988): Official Syllabus, Jerusalem, Israel.

Ministry of Education (1990): Translation skills, English-Hebrew, Hebrew-English, Jerusalem, Israel.

NAIMAN, N., FROEHLICH, M., STERN, N. H. \& A. TODESCO (1978): The Good Language Learner, Ontario Institute for Studies in Education. (Quoted by Levenston, 1985a)

RIVERS, W. (1991): "Reflections on language learning and teaching", English Teaching Forum, XXIX (1), pp 2-5.

REGBERG, R. M. (1958): English as a Foreign Language, Tel Aviv, "Otzar Hamoreh", Teachers' Union, Israel.

ROSENBLÜTH, P. \& N. BALLAS (in preparation): Two Way Traffic: The Practice of Translation, Ministry of Education, Jerusalem, Israel.

RUBIN, J. (1975): "What the 'good language learner' can teach us", TESOL Quarterly, 9 (1), pp. 41-51.

RUBIN, J. (1987): "Learner strategies: Theoretical assumptions, research history and typology", A. Wenden \& J. Rubin (Eds), Learner Strategies in Language Learning, New Jersey, Prentice-Hall, pp. 15-30.

SAVIGNON, S. (1987): "What's what in communicative language teaching", English Teaching Forum, XXV (4), 64, pp. 16-24.

SHARWOOD SMITH, M. (1981): "Consciousness raising and the second language learner", Applied Linguistics, 11 (2), pp. 159-168.

SKINNER, B. F. (1938): Behavior of Organisms: An Experimental Analysis, New York, Apelton-CenturyCrofts.

STEINER, J. (1995): "Announcements regarding the Bagrut examinations", English Teachers' Journal (Israel), 48, pp. 19-23.

TEMPLETON, S. (1989): "Tacit and explicit knowledge of derivational morphology: Foundations for a unified approach to spelling and vocabulary development in the intermediate grades and beyond", Reading Psychology, 10, pp. 233-253.

THOMAS, J. (1988): "The role played by metalinguistic awareness in 2nd and 3rd language learning", Journal of Multilingual and Multicultural Development, 9 (3), pp. 235-246.

TITFORD, C. (1983): "Translation for advanced learners", English Language Teaching Journal, 37 (1), pp. $52-$ 57.

TITONE, R. \& M. DANESI (1985): Applied Psycholinguistics: An Introduction to the Psychology of Language Learning and Teaching, University of Toronto Press.

VIEIRA, F. (1991): "Language awareness and language learning", English Teaching Forum, XXIX (2), pp. 37 41.

WATSON, J. B. (1913): "Psychology as the behaviorist views it", Psychological Review, 20, pp. 158-177.

WEIZMAN, E. \& E. KOZMINSKY (in preparation): Metalinguistic Awareness and L2 Development.

WENDEN, A. \& J. RUBIN (Eds) (1987): Learner Strategies in Language Learning, New Jersey, Prentice-Hall. 